\title{
10 Bottom-up Approaches to the Regularisation of Undocumented Migrants
}

\author{
The Swiss Case
}

Lucia Della Torre

\begin{abstract}
Silence seems to have fallen yet again on the fate of those who, though most of the time significantly contributing to European States' economies, are presumed invisible by those same States' governments and administrations. The Swiss stance towards undocumented migrants has, for quite some time, mirrored the European one of - at best -isolation and indifference. Yet, it is precisely from Switzerland that a new attempt to promote the regularisation of Sans-Papiers has very recently arisen. Coming from a Cantonal government, this operation resembles the creative practices of social inclusion already experimented with in some communities. Unlike the latter, however, this Swiss operation received the endorsement of the Federal Government, thus presenting itself as an example of 'Swiss pragmatism', which could become an interesting model for other European countries.
\end{abstract}

Keywords: regularisation, undocumented migrants, Swiss policy, social inclusion

Rijken, Conny and Tesseltje de Lange (eds): Towards a Decent Labour Market for Low Waged Migrant Workers. Amsterdam: Amsterdam University Press, 2018 DOI: $10.5117 / 9789462987555$ TORR 


\section{Introduction}

If migration represents, generally speaking, a 'challenge to the Nation State', all the more so can be said about irregular (economic) migration:' those who enter and take residence within the State in breach of its migration provisions openly defy its control over its borders and its population, with the risk of increasing social discontent and eventually creating political instability. ${ }^{2}$ It is common knowledge that, in trying to reassert their sovereignty over their national territories, States have enacted ever more restrictive immigration policies over the years, but not all the measures that States have taken to address irregular migration are 'exclusionary' in nature. In some cases, States have decided to adjust to, rather than fight against, undocumented people, or Sans-Papiers. The tools that they primarily use to do so are regularisation programs, i.e. 'broad legal shifts through which a group of people without immigration status or a legal right to remain are granted that right', and regularisation mechanisms, which, on the contrary, operate on a case-by-case basis. ${ }^{3}$ Such measures were, in fact, quite broadly used between the mid-199os and the first years of the 21st century: the practice of Southern European

1 S. Schech (2013), 'Rescaling sovereignty?', Griffith Law Review, 22, pp.758-803. 'Irregular migrant' is used here to describe people who migrate without established travel arrangements (IOM World Migration Report 2008) and/or who do not have the legal status to allow them to live permanently in the country of destination (Nyers, 2010). Using this term does not make any presumptions about the legitimacy of the migrant's reasons for migrating.

2 S. Joppke (1998), Challenge to the Nation-State, Oxford: Oxford University Press; See also

S. Blinder and B. Allen (2016), UK Public Opinion toward immigration: overall attitudes and Level of Concern. Retrieved from: http://www.migrationobservatory.ox.ac.uk/wp-content/ uploads/2016/o4/Briefing-Public_Opinion_Immigration_Attitudes_Concern.pdf. According to the study, $34 \%$ of the respondents picked 'immigration' as the most important issue facing the nation. The think tank Chatham House carried out a survey according to which: 'overall, an average of 55\% [of interviewees] agreed that all further migration from mainly Muslim countries should be stopped'. Results and further comments available online at: https://www. chathamhouse.org/expert/comment/what-do-europeans-think-about-muslim-immigration.

3 D. Dauvergne (2008), Making people illegal, Cambridge: Cambridge University Press. p. 139. On regularisations, see, among others: P. de Bruycker (2000), Les regularisations des étrangers illégaux dans l'Union Européenne/Regularisations of illegal immigrants the European Union. Brussells: Bruyant; J. Apap, P. de Bruycker, and C. Schmitter (2000), 'Regularisations of Illegal Aliens in the European Union. Summary Report of a Comparative Study,' European Journal of Migration and Law, pp. 263-308; A. Levinson (2005), The Regularisation of Unauthorized Migrants: Literature Survey and Country Case Studies, Oxford: Centre on Migration, Policy and Society, retrieved from: https:// www.compas.ox.ac.uk/media/ER-2005-Regularisation_Unauthorized_Literature.pdf; D. Papademetriou (2005), The regularisation option in managing illegal migration more effectively: a Comparative Perspective, MPI policy brief, retrieved form: http://www.migrationpolicy.org/research/ regularization-option-managing-illegal-migration-more-effectively-comparative-perspective. 
States (Italy, Greece, and Spain) to enchain one 'one-shot' general amnesty after the other had even sparked the dismay of some of their Northern European counterparts. ${ }^{4}$ The use of these tools (especially large regularisation programs) began to decrease after the 'moral panic' that followed the $9 / 11$ attacks on American soil, and practically came to an end with the economic crisis of 2008, which brought along increased discontent towards economic migration. ${ }^{5}$ While in 2007 the Council of Europe maintained that 'if it is not possible to return [irregular migrants] then Member States should consider the option of regularising their situation', in 2008, the Council of the European Union specified that Member States should refrain from using 'generalised amnesties', rather preferring 'case-by-case' regularisations. ${ }^{6}$ In addition, while in 2009 the European Commission suggested that European guidelines for the implementation of regularisations should be set, together with common standards on irremovable irregular immigrants, neither of the two points was mentioned in the final version of the Stockholm Programme, endorsed at the end of that same year. ${ }^{7}$

4 The frequent use of amnesties by Southern European States had caused some frictions with Northern European States, generally more reluctant to use broad regularisation programmes. In this sense, see: C. Finotelli and J. Arango (2011), 'Regularisation of unauthorised immigrants in Italy and Spain: determinants and effects', Documents d'Analisi Geografica, 57, pp. 494-515. Some European countries clearly withdrew from regularisations in other Member States. After the 2002 Italian regularisation, representatives of certain Member States attempted to exclude regularised immigrants from the categories encompassed by the European directive on long-term residents from third countries. Furthermore, in 2005, both the German and Dutch governments sharply criticised the decision by the Spanish government to carry out a mass regularisation of irregular immigrants. The same government was also blamed for not having informed its fellow EU Member States about the process in an adequate time frame. In particular, German and Dutch criticism was fueled by a widespread fear that regularised immigrants in Spain would invade other EU Member States, attracted by their generous welfare systems.

5 S. Hauptman (2013), The Criminalization of Immigration. Post 9/1 Moral Panic, El Paso: LFB Scholarly Publishing LLC.

6 Council of Europe, Parliamentary Assembly (6 July 2007), Regularisation Programmes for irregular migrants, Report, Doc. 11350, and Council of the European Union (24 September 2008), European Pact on Immigration and Asylum, 13440/o8, Brussels. Many studies were also commissioned on the topic. Apart from the known Clandestino Project (European Commission, 'Clandestino Project Final Report', 2009, available at: http://www.gla.ac.uk/media/ media_147171_en.pdf), see also: Council of Europe Parliamentary Assembly and J. Greenway (2007), Regularisation programmes for irregular migrants, available at: http://www.unhcr. org/4b9fac519.pdf; ICMPD (2009), 'Regine - Regularisations in Europe. Final Report', Vienna, Austria, available at: http://ec.europa.eu/home-affairs/doc_centre/immigration/docs/studies/ regine_report_january_2009_en.pdf.

7 European Commission (10 June 2009), Communication on an Area of Freedom, Security and Justice serving the citizen: Wider freedom in a safer environment, COM (2009) 262, Brussels. For an analysis of these texts, see: E. Guild and S. Carrera (August 2009), Towards the Next Phase 


\section{Theoretical Framework}

Almost ten years after the economic breakdown of 2008, the landscape does not seem to have changed much. Silence seems to have fallen on the fate of undocumented migrants in Europe, their presence overshadowed by issues related to the significant number of new arrivals over the past years. While more 'attractive' migrants such as students, highly skilled, or intra-corporate transferees are quite well looked after ${ }^{8}$, there are very few European legislative provisions that relate to low-skilled/unskilled migrant workers who, on the other hand, constitute the great majority of the Sans-Papiers population. ${ }^{9}$

The most prominent example, the Seasonal Worker Directive (see Zoeteweij in this volume), only targets 'new arrivals' (and circular migration): it thus refrains from taking into account the situation of those already present within the Schengen Space who, on the other hand, might have benefited from a directive related to low-skilled labour, had it been retroactively applicable. The main provisions that affect the situation of Sans-Papiers thus remain those that criminalise their irregular status (Facilitator unauthorized entry Directive, 2002/90/EC, Employers' Sanctions Directive, 2009/52/EC, Returns Directive, 2008/115/EC; see Berntsen and De Lange in this volume), conveying the message that undocumented migration should not be tolerated. Also, single Member States have become more cautious in the use of regularisation measures and have, at the same time, both tightened their grip over national borders and increased pressure on irregular migrants already present in their territories, fast-tracking deportation and expulsion measures and making broad use of criminal and administrative detention, alongside strong anti-immigration rhetoric.

At European and national levels, laws are thus framed and policies passed that primarily aim at excluding and removing irregular migrants, often making their access to very basic human rights such as health, housing, or education particularly difficult. Yet, 'the incapacity of certain

of the EU's Area of Freedom, Security and Justice: The European Commission Proposals for the Stockholm Programme, CEPS Policy Brief No. 196, Centre for European Policy Studies, Brussels. And S. Carrera and M. Merlino (October 2010), Assessing EU policy on irregular immigration under the Stockholm Programme, CEPS, Centre for European Policy Studies, Brussels.

8 Student Directive, 2004/114/EC: Blue Card Directive, 2009/5oEC: Intra-Corporate Transfers directive, 2014/66/EU

9 The fact that Sans-Papiers are mostly active in the low/unskilled fragments of the job market is, for example, highlighted by the Clandestino Project; see, for instance, pp. 49, 84, 89, and 135 of the 'Final Report'. 
national immigration legislation in terms of meeting local social realities and ensuring that those who reside in their territories have access to basic socio-economic rights has led to situations whereby local actors (mainly cities) have been encouraged to develop "creative“ (informal) practices for social inclusion, community well-being and the provision of services to all their residents' ${ }^{10}$ Such practices, which, without legally regularising it, do somehow 'normalise' the situation of undocumented migrants, are often carried out without, or even in defiance of, national directives and policies on irregular migration. ${ }^{11}$ With the passing of time, the void left by European and national legislative indifference towards the fate of Sans-Papiers has thus been filled by bottom-up initiatives, fostered by grassroots movements that sensitise the population to the vulnerability of undocumented migrants and progressively facilitate their integration into the hosting society. These strategies bring to the fore the role that cities can play in the management of the migration process: academic research has already investigated the very significant contribution that municipalities make to improve the conditions of those Sans-Papiers living within their territory. ${ }^{12}$

Research dedicated to the inclusion policies enacted at the intermediate level between the two poles of State and municipality is less developed, conveying the impression of a dichotomous management of migration, torn

10 S. Carrera and M. Merlino, Assessing EU policy on irregular immigration under the Stockholm Programme, p. 7. See also: B. Barber (2013), If Mayors Ruled the World: Dysfunctional Nations, Rising Cities, Yale: Yale University Press.

11 E. Hepburn and R. Zapata-Barrero (2014), 'Introduction: Immigration Policies in Multilevel States', in R. Zapata Barrero and E. Hepburn (eds.) The Politics of Immigration in Multi-level States, New York: Palgrave, p. 5: 'Sub-state governments and parties may adopt quite distinctive policies on migration, which may diverge from, or even contradict, those of the State [...] often, these sub-state political approaches to immigration conflict directly with central-state (national) models, resulting in tensions over policy coordination and the framing of immigration in different parts of a country'.

12 On the topic, amongst others: T. Caponio (2005), 'Policy networks and immigrants' associations in Italy. The cases of Milan, Bologna and Naples', Journal of Ethnic and Migration Studies, 31 pp. 931-950; M. Alexander (2007), Cities and labour immigration. Comparing policy responses in Amsterdam, Paris, Rome and Telaviv, Aldershot: Ashgate; P. Neyers and K. Rygiel (eds.) (2012), Citizenship, Migrant Activism and the Politics of Movement London: Routledge; P. Neyers (2012), 'No One is Illegal between City and Nation', Studies in Social Justice, 4(2) pp. 127-143; R. Dekker, H. Emilsson, B. Krieger, and P. Scholten (2015), 'A Local Dimension of Integration Policies? A comparative Study of Berlin, Malmo and Rotterdam', International Migration Review, 49(3) pp. 633-658; H. Bauder (2017), 'Sanctuary Cities: Policies and Practices in International Perspective', International Migration, 55(2) pp. 174-187. See also the website of the EUROCITIES network. Retrieved from: http://www.eurocities.eu/eurocities/issues/migration-integration-issue. The experience of CLIP (Cities for Local Integration Policies) can also be mentioned: https://www. eurofound.europa.eu/clip-european-network-of-cities-for-local-integration-policies-for-migrants 
between rigid national attitudes, and (in some happy cases) more welcoming local ones. ${ }^{13}$ However, this approach risks overlooking some interesting examples in which effective 'normalisation' processes are carried out at a subnational, but not yet municipal level. ${ }^{14}$ Such cases are of particular interest because they are likely to involve a higher number of undocumented migrants and therefore have a bigger impact than merely municipal operations. Furthermore, practices recognised at a federal/regional level may have a more official character (and therefore more stability) than those only practised at a municipal level. In most of these cases, they would still only impact the undocumented migrants' everyday lives, making them easier and safer, but, in some situations, they may end up impacting their official migration statuses. In these occurrences, they may practically turn into real regularisation mechanisms, thus adding an additional layer to the multifaceted legal framework related to the management of irregular migration. ${ }^{15}$

This latter possibility has been concretely enacted by a Swiss regularisation programme that began in 2017 in Canton Geneva, which will be discussed in the present paper. The discussion will be structured as follows: the first part will provide a brief overview of the functioning of the Swiss system in general, then zoom in on the framework related to irregular migration. We will then focus on the Papyrus Operation, presenting its main characteristics and elements of originality. Finally, we will draw a comparison between

13 'Local policy is essentially identified with city level policy and, even more narrowly, with the interventions carried out by local/municipal administrations', M. Borkert and T. Caponio (2010), Introduction, in C. Tiziana and B. Maren (eds.), The local dimension of migration policy and policymaking, Imiscoe Report Series, Amsterdam: Amsterdam University Press.

14 Very interesting in this respect is the case of Catalonia: on the basis of the Statute of Autonomy of 2006, the Catalan government is able to pass legislation on the reception of migrants and to formulate, within the limits of its devolved powers, its own integration policies. S. Schech, in 'Rescaling Sovereignty?' mentions 'the Catalan Citizenship and Immigration Plan (2005-2008) [which] makes residency in Catalonia the sole criterion for a migrant's inclusion in public policies and access to services'. See also: M. Bruquetas-Callejo et al. Immigration and Integration Policy-making in Spain, IMISCOE Working Paper 21, 2008; À. Castiñeira (2009), Immigration in Multinational States: The Case of Catalonia, in R. Zapata Barrero (ed.), Immigration and Self-Government of Minority Nations, Bern: Peter Lang.

15 E. Hepburn and R. Zapata-Barrero, Introduction:Immigration Policies in Multilevel States, p. 6: 'As immigration has become 'rescaled' across several levels of multilevel states, there is an urgent need to develop a deeper understanding of how immigration is governed and framed by political actors across different territorial levels [...] since the elaboration of multilevel governance, there have been far fewer examinations of this multilevel perspective at the state/sub-state political level, nor has it ever been examined with regard to the specific area of immigration, which is clearly a cross-cutting policy issue that affects both levels'. 
this experiment and other similar ones already carried out in Europe, and we will close with a tentative assessment of whether such a model could ever be implemented outside of Switzerland.

\section{Swiss Federalism and Migration Management}

The Swiss confederation consists of 26 Cantons: each canton -- with its own territory, population, financial resources, and political power -- represents one almost statuary entity. Despite not being sovereign in external relations and also not fully independent in some internal matters, cantons enjoy a very significant degree of independence. ${ }^{16}$ Swiss federalism is oftentimes presented as 'federalisme d'execution' (which could be translated as 'executive federalism') because, while the federal government retains legislative responsibility, the implementation of the single normative provisions is delegated to each single canton, thus allowing a high degree of policy-making autonomy in such areas as education, health, and policing. While this type of organisation allows adaptation of the federal law to the specific situation of each single canton, such a high level of autonomy can lead to significant policy differences between one canton and another.

Such differences are particularly sharp when it comes to the implementation of national provisions in the field of migration: from the process of naturalisation to the one of renewal of long-term or short-period permits, cantons have the liberty to shape the general requirements set out in national legislation according to their own social, economic, and political specificities. ${ }^{17}$ The same goes for the implementation of the only provision that allows for the regularisation of undocumented migrants present in the country, namely art. 30, al. 1, lett. b of the Law on Foreigners.

According to this provision, 'derogations from the admission requirements are permitted in order to [...] b. take account of serious cases of personal hardship or important public interests'. The content of the normative provision is further specified by an administrative memorandum, the OASA (Ordinance on admission, residence and economic activity), which states (art. 31) the criteria that should be taken into account when assessing a

16 Art. 3 of the Swiss Constitution, and Title 3 , Ch. 1, Sect. 1, artt. 42-49. See also H. Kriesi (1998), Le systeme politique suisse, Paris: Economica.

17 N. Wichmann, M. Hermann, G. D'Amato, D. Efionay-Mader, R. Fibbi, J. Menet, D. Ruedin (2011), Les marges de manœuvre au sein du fédéralisme: La politique de migration dans le cantons, Commission fédérale pour les questions de migration, Bern: CFM, retrieved from: https://www. ekm.admin.ch/dam/data/ekm/dokumentation/materialien/mat_foederalismus_f.pdf. 
claim for 'serious case of personal hardship'. According to this framework, a Sans-Papier willing to apply for regularisation needs, first of all, to show good integration into the country and, secondly, respect for the Swiss legal order. The third and fourth criteria relate to the claimant's family and economic situation: in respect to the former, special attention is paid to the situation of the claimant's children; in respect to the latter, the claimant's ability and willingness to work will also be evaluated, thus becoming the fifth object of scrutiny. The sixth element to be taken into account is related to the length of the migrants' presence in Switzerland. The administrative guidelines clearly state that neither 'the law, nor the jurisprudence of the Federal Tribunal explicitly foresee a minimum or a maximum length of stay [for the claim to be considered or to succeed]'. Nevertheless, possibly taking into account other normative references that are present in the Law on Foreigners (art. 84, al. 5) and in the Law on Asylum (art. 14, co. 2), the same guidelines state that 'a presence of five years in Switzerland should be considered as a relevant indicator'. The seventh and the eighth elements relate to the health status of the migrant and to the migrant's possibility to reintegrate into his or her country of origin. ${ }^{18}$

Migrants who would like to avail themselves of the provisions contained in art. 30 , lett. $b$ of the Federal Act should address their requests to the local migration authority, which gives a first consideration to the dossier and decides whether to pass it on to the central administrative authority on migration (State Secretariat for Migration), which gives the final decision. As art. 30, para. 1, lett b) was redacted as a 'may' and not as a 'shall' clause, there is no right for the migrant to be granted the permit - the concession of it depends solely on the discretionary evaluation of the administrative authority. The decision of the central authority on the dossier is free and does not necessarily have to take into account the evaluations of the local authority. On the other hand, statistics show that once the dossier has made it to the second step of the bureaucratic structure, the rate of approval is

18 M. Caroni, T. Grasdorf-Meyer, L. Ott, and N. Scheiber (2014), Migrationsrecht, Stämpfli Verlag: Bern, p. 19; D. Efionay-Mäder, S. Schönenberger, and I. Steiner (2010), Visage des Sans-Papiers en Suisse, Federal Commission for Migration. Retrieved from: https://www.ekm.admin.ch/ dam/data/ekm/dokumentation/materialien/mat_sanspap_f.pdf; M. Morlok, A. Oswald, H. Meier (B,S,S.), D. Efionayi-Mäder, D. Ruedin, D. Bader, and P. Wanner (2015), Les Sans-Papiers en Suisse en 2015, State Secretariat for Migration. Retrieved from: https://www.sem.admin.ch/ dam/data/sem/internationales/illegale-migration/sans_papiers/ber-sanspapiers-2015-f.pdf; R. Petry (2013), La situation juridique des migrants sans statut legal, Geneva: Schulthess; E. Piguet, 'Quotas d'Immigration: L'expérience Suisse' Retrieved from: http://www2.unine.ch/repository/ default/content/sites/sfm/files/shared/pub/o/o_o3.pdf. 
quite high - in other words, the federal office tends to rely on the evaluations made by the cantons and to stand by their decisions. The decision of the local authority not to pass the dossier on to the federal office can be appealed before the cantonal tribunals according to the provisions of the cantonal law. The decision of the federal office can be appealed to the Federal Administrative Tribunal. The procedure clearly follows a path that takes into account the specific structure of the Swiss administration, first allowing the local authorities to have their say on the claim and then passing the dossier on to the central level.

As is apparent by the very structure of the norm, what is crucial in every aspect is the way each single canton decides to decline the very broad requirements set out in the OASA. Recent studies have confirmed that the rates of regularisation for individuals are extremely varied from one canton to another: it is thus very difficult, if not impossible, for an individual to be able to predict the outcome of his or her application, which clearly discourages interested people from applying and thus keeps the number of irregular permanencies quite stable. ${ }^{19}$ The elbow room is so broad that scholars agree that this Swiss regularisation mechanism is extremely patchy and not very effective. It is even argued by some, whether such a tool deserves the name of 'regularisation mechanism' at all. ${ }^{20}$ This trend is, on the other hand, very much in line with the official stance that Switzerland has on migration, which, traditionally cautious, has become very restrictive with the passing of the new Law on Foreigners in 2008. ${ }^{21}$

19 According to Philippe Wanner (2015), in Les Sans-Papiers en Suisse en 2015, the number of undocumented migrants in the country is around 76000 . On the very limited legal certainty that Sans-Papiers can rely upon when submitting their application, see again D. Efionay-Mäder, S. Schönenberger, and I. Steiner (2010), Visage des Sans-Papiers en Suisse: 'la décision d'examiner les demandes de cas de rigueur ainsi que l'interprétation et la pondération des critères sont laissés à l'appréciation des cantons [...] les requérants, mais également les organisations de soutien, ignorent toujours quels sont les critères décisifs pour l'acceptation des demandes de cas de rigueur par les cantons et les autorités fédérales. Aucun des spécialistes interrogés n'était réellement à même de définir des critères de décision manifestes et transparents. Ainsi, peu de Sans-Papiers prennent le risque de déposer une demande, puisqu'ils sont obligés de décliner leur identité et qu'en cas de décision négative, ils risquent le renvoi. Même les services de consultation sont extrêmement prudents lorsqu'ils évaluent l'opportunité du dépôt d'un dossier et parfois ils le déconseillent aux personnes concernées'.

20 R. Diethelm (2016), La régularisation des Sans-Papiers a l'aune de l'art. 30 al 1 let. B Letr, Actualité du droit des étrangers. Jurisprudence et analyses, ed. by Gaëlle Sauthier and Minh Son Nguyen, Bern: Stämpfli Verlag pp. 1- 28.

21 M. Caroni (2016), 'Die rechtliche Stellung der Sans-Papiers verbessern', in C. Abbt and J. Rochel (eds.), MigrationsLand Schweiz.15. Vorschlage für die Zukunft, Lucerne: Hier und Jetzt, pp. 103-116. 


\section{Operation Papyrus}

Against this background, a very recent case has emerged, under the name 'Papyrus Operation'. The Canton of Geneva is amongst the richest and most highly populated in Switzerland, with a traditionally open attitude towards immigration. Almost $40 \%$ of the population is foreign, and the territory also has one of the highest percentages of regularisation by way of art. 30, al. 1, lett. b).

At the beginning of the $21^{\text {st }}$ century, an attempt had already been made to ask for the regularisation, at the cantonal level, of all the Sans-Papiers working in the domestic economy, but the initiative was not successful. ${ }^{22}$ Yet, lawyers and legal experts operating in associations representing and supporting irregular migrants kept the channels of communication with the cantonal authorities open. In turn, the latter remained aware of the presence of the roughly 13000 undocumented migrants in the canton. In 2011, with a mandate of the Conseil d'Etat, the highest executive authority in the canton, a group of experts finally had the chance to take concrete action. This was done by sampling cases that would stand a good chance of being regularised via the usual procedure, and drawing from them common characteristics that, in turn, could be used to revitalise the extenuated criteria set out in the OASA. These common elements were then converted into general requirements to be complied with in order to qualify for the new case-by-case regularisation programme that would be enacted by the canton.

The newly drafted provisions, while entirely respecting the guidelines set out in art. 30, al. 1, lett. b) of the Law on Foreigners, also materialised them into clear-cut and concrete provisions, reducing the discretion of the single decision maker. The applicants would now know that, in order to be able to submit their request, they would need to show complete financial independence (though without having to sustain further enquiries on the level of success attained with their professional activity, for instance), effective integration into the host society (which is simply proven with an A2 level of French), no criminal records, and ten years of uninterrupted stay in the territory of the canton ( 5 for families with school-aged children). Additionally, the drafters removed the requirement related to the possibility or impossibility for the applicants to return to their country of origin, which

22 The proposition came from the Conseil d'État, and aimed at a case-by-case regularisation of domestic workers living in the Canton. See, for instance, the Press-communicate of 5 April 2005. Retrieved from: https://www.ge.ch/conseil_etat/2005-2009/communiques/20050406.asp. 
somewhat confused the intent of art. 30, al. 1, lett b), blurring the lines between regularisations for so called 'humanitarian reasons' on the one hand, and 'economic regularisations' on the other. ${ }^{23}$

Once the criteria were drafted, the group of experts and the cantonal authorities engaged in multiple meetings with their federal counterparts, in order to define in detail all the aspects of the procedure, which then ceased to be only an 'internal' matter, becoming instead an official project, known and endorsed by the national authorities. This passage was of crucial importance. As seen previously, after a preliminary evaluation by the canton, the Sans-Papier's dossier needs to be evaluated by the State Secretariat for Migration for final approval. Without the support of the federal authorities, the whole procedure would thus remain at the level of the practices we have mentioned at the beginning of this contribution, which, though facilitating undocumented migrants' lives, do not assure them a secure legal status outside the city or town (or canton) of reference. Federal administration instead granted its support to the initiative, and thus committed to look favourably at the dossiers that, coming from Canton Geneva, would comply with the newly developed requirements. National authorities took a positive stance because cantonal ones took the commitment, through the regularisation of the Sans-Papiers, to bring the underground economy of some labour markets (mostly domestic work, but also construction and services) to the surface. The Government of the Canton of Geneva officially launched the operation on 21 February 2017.

The authorities have carefully stressed that this should, in no way, be considered as amnesty, in the sense that each individual application will be assessed on its merits, and there is no automatic guarantee of a positive outcome. Yet, Operation Papyrus presents a significant improvement for the condition of the Sans-Papiers living in the Canton of Geneva in comparison with that of undocumented migrants living elsewhere in the country because, as said, this time the content of the broad criteria listed in art. 30, al. 1, lett. b) Law on Foreigners has been spelled out. Through this operation, Canton Geneva takes a stand against the excessive discretion of the cantonal authorities in the implementation of the 'personal hardship' provision and against the consequent lack of transparency of the criteria

23 R. Petry (2017), La situation juridique des migrants sans statut legal; L. Della Torre (2017), State's Discretion and the Challenge of Irregular Migration - the Example of Permanent Regularization Practices in Spain and Switzerland, NCCR Working Papers. Retrieved from: http:// nccr-onthemove.ch/publications/states-discretion-and-the-challenge-of-irregular-migrationthe-example-of-permanent-regularization-practices-in-spain-and-switzerland-2/ 
used to interpret this provision. This change, besides possibly facilitating the tasks of the administrative personnel called upon to apply the legal requirements should, most of all, make it easier for undocumented migrants to foresee the results of their requests, thus increasing their trust in the system and, ultimately, allowing them to take concrete steps to get out of their precarious status.

\section{Analysis and Conclusions}

The operation launched by Canton Geneva is the first of its kind ever tried in Switzerland. Yet, it can be placed against the broader framework represented by other de-irregularisation practices already well-established in other parts of Europe, with some very peculiar elements of distinction.

As anticipated at the beginning of the paper, in many cities, the common practice is to normalise the situation of Sans-Papiers substantially, through the use of informal routines that allow them to carry on a relatively safe life, e.g. refraining from asking them for papers when they attend hospitals, and allowing their children to go to school. In some cases, such as in the American 'sanctuary cities', for example, this support goes one step further, becoming something of a challenge towards the central government. In these 'sanctuary cities', local authorities refuse to carry out removal orders or to report Sans-Papiers migrants to the local police forces, thus de facto voiding national provisions and law enforcement measures and eliminating much of their effectiveness. ${ }^{24}$

With all their many specificities and differences, it seems that the protection mechanisms for Sans-Papiers at a local level share some common elements. First of all, and as with almost anything that relates to undocumented migrants, they are para-legal, in the sense that it is difficult to place them within a firm legal framework. Furthermore, they are generally carried out in the face of opposition - or, at best, indifference - from the national authorities: thus, even when not only implemented by civil society, but also endorsed by local authorities, such mechanisms generally do not have any effect outside the municipality that implements them. Finally, while the arguments behind these practices may sometimes make reference to the positive role that irregular migrants could play in addressing local labour shortages, they are mostly human rights-based, structured on the assumption that granting protection to Sans-Papiers is the only way to make sure 
that they are effectively in the position of exercising those human rights to which they should be entitled.

The Swiss case is very interesting because it adds new elements to the ones we have considered up to this point. It is still an operation launched only at a local, even if not municipal, level: as such, it has a broader effect than municipal practices, but, at the same time, it does not reach the national level. It is thus by no means to be confused with a national regularisation programme. Similar to local practices of support and protection for irregular migrants, Operation Papyrus was also prepared by the intense work of the local organisations acting for the support and assistance of migrants. It is thus, by all standards, a 'bottom-up' operation, which, over the years, has managed to gain acknowledgement of the cantonal authorities. At the same time, though, despite being a 'bottom-up' operation, it is much more effective and much more pervasive than the ones generally carried out at a municipal level: the operation does not content itself with facilitating the access of migrants to school, education, health care, and the like; rather, it grants these migrants a permission to remain that, once obtained, is viable throughout the country. This was possible because, and this is the second element that sets the Geneva example apart, the operation was not carried out against federal authorities, but in accordance with them. Finally, while the human rights approach certainly played a part in the motivations and pursued goals of those directly involved in the drafting of the Papyrus criteria, the economic goal of facilitating the emergence of some half-hidden and highly precarious labour sections was important to gain the attention and support of the cantonal and federal authorities.

Despite its severe official stance against irregular migration, Switzerland has thus managed to establish itself as one of the first countries in Europe that has allowed a regularisation procedure to take place at the local level, at the same time granting it national validity.

Such an operation was made possible by the combination of multiple factors. The peculiar conditions of Canton Geneva, very rich in migrant population and traditionally open to foreign work, need to be considered, as well as the very effective mobilisation of the organisations supporting irregular migrants. To this, the very peculiar characteristics of the Swiss Federalism and the great margin of manoeuvre granted to cantons in the handling of migration need to be added, together with a touch of that 'Swiss pragmatism' that entails shying away from all-inclusive theoretical approaches, refusing generalised definitions of any modus operandi and, on the contrary, favouring a very concrete and case-by-case approach. 
It is difficult to foresee whether such elements could be reproduced again, either inside or outside of Switzerland. As for the national level, the same pragmatic approach that allows for the possibility of reaching tailored and effective solutions also brings along the risk of fragmentation, and of 'conducting a sectoral policy, disregarding a coherent overview'. ${ }^{25}$ Some cantons have already specifically declared that they will not enact such operations as Papyrus in their territory, and the occurrence of a patchwork legal framework for Sans-Papiers in the country thus becomes a concrete possibility. As for the international level, it remains to be seen whether other European states will ever allow municipalities and regional governments to enjoy the same elbow room as their Swiss counterparts, and whether they will be capable of structuring a regularisation reform that does not defy, but rather persuades, national authorities.

Migration is one of the phenomena that most challenge states to reassert their sovereignty and their power. Yet, it is precisely in this field that sovereignty is being rescaled. The impact and the persuasiveness of the Swiss example make a case of their own, but, at the same time, they confirm that the subnational level is the one where some of the most interesting attempts are made to absorb foreign population, to integrate it, and to overcome anti-immigration rhetoric, and, thus, the need to continue monitoring it. Switzerland, with its peculiar federal structure, could be, in this sense, an excellent laboratory.

\section{Bibliography}

Alexander, M. (2007), Cities and labour immigration. Comparing policy responses in Amsterdam, Paris, Rome and Telaviv, Aldershot: Ashgate.

Apap, J.; P. de Bruycker; and C. Schmitter (200o), 'Regularisations of Illegal Aliens in the European Union. Summary Report of a Comparative Study', European Journal of Migration and Law,2, (3) pp. 263-308.

Barber, B. (2013), If Mayors Ruled the World: Dysfunctional Nations, Rising Cities, Yale: Yale University Press.

Bauder, H. (2017), 'Sanctuary Cities: Policies and Practices in International Perspective', International Migration, 55(2) pp. 174-187.

Borkert, M. and T. Caponio (2010), 'Introduction', in C. Tiziana and B. Maren (eds.), The local dimension of migration policy and policymaking, Imiscoe Report Series, Amsterdam: Amsterdam University Press.

25 M. Francesco (2011), La ou des inconvénients du pragmatisme helvétique dans la gestion des rapports entre droit européen, droit bilatéral et droit interne, Revue de droit Suisse, pp. 27-53. 
De Bruycker, P. (2000), Les regularisations des étrangers illégaux dans l'Union Européenne/Regularisations of illegal immigrants the European Union. Brussells: Bruyant.

Caponio, T. (2005), 'Policy networks and immigrants' associations in Italy. The cases of Milan, Bologna and Naples', Journal of Ethnic and Migration Studies, 31 pp. 931-950.

Caroni, M.; T. Grasdorf-Meyer; L. Ott; and N. Scheiber (2014), Migrationsrecht, Bern: Stämpfli Verlag, p. 19 .

Caroni, M. (2016), 'Die rechtliche Stellung der Sans-Papiers verbessern', in C. Abbt, J. Rochel (eds.), MigrationsLand Schweiz. 15 Vorschlage fur die Zukunft, Lucerne: Hier und Jetzt, pp. 103-116.

Carrera, S. and M. Merlino (October 2010), Assessing EU policy on irregular immigration under the Stockholm Programme, Centre for European Policy Studies (CEPS), Brussels.

Dauvergne, D. (2008), Making people illegal. Cambridge: Cambridge University Press.

Dekker, R.; H. Emilsson; B. Krieger; and P. Scholten (2015), 'A Local Dimension of Integration Policies? A comparative Study of Berlin, Malmo and Rotterdam', International Migration Review, 49(3) pp. 633-658.

Della Torre, L. (2017), State's Discretion and the Challenge of Irregular Migration the Example of Permanent Regularization Practices in Spain and Switzerland, NCCR [National Centre for Competence in Research] Working Papers.

Diethelm, R. (2016), La régularisation des Sans-Papiers a l'aune de l'art. 30 al 1 let. $B$ Letr, Actualité du droit des étrangers. Jurisprudence et analyses, ed. by Gaëlle Sauthier and Minh Son Nguyen, Bern: Stämpfli Verlag pp. 1- 28.

Efionay-Mäder, D.; S. Schönenberger; and I. Steiner (2010), Visage des Sans-Papiers en Suisse, Federal Commission for Migration.

Finotelli, C. and J. Arango (2011), 'Regularisation of unauthorised immigrants in Italy and Spain: determinants and effects', Documents d'Analisi Geografica, 57, pp. 494-515.

Guild, E. and S. Carrera (August 2009), Towards the Next Phase of the EU's Area of Freedom, Security and Justice: The European Commission Proposals for the Stockholm Programme, CEPS Policy Brief No. 196, Centre for European Policy Studies, Brussels.

Hauptman, S. (2013), The Criminalization of Immigration. Post 9/11 Moral Panic, El Paso: LFB Scholarly Publishing LLC.

Hepburn, E. and R. Zapata-Barrero (2014), 'Introduction: Immigration Policies in Multilevel States', in The Politics of Immigration in Multi-level States, New York: Palgrave, pp. 3-18.

Joppke, S. (1998), Challenge to the Nation-State. Oxford: Oxford University Press. Kriesi, H. (1998), Le systeme politique suisse, Paris: Economica. 
Levinson, A. (2005),The Regularisation of Unauthorized Migrants: Literature Survey and Country Case Studies, Oxford: Centre on Migration, Policy and Society.

Morlok, M.; A. Oswald; H. (B.S.S.) Meier; D. Efionayi- Mäder; D. Ruedin; D. Bader; and P. Wanner (2015), Les Sans-Papiers en Suisse en 2015, State Secretariat for Migration.

Neyers, P. (2012), 'No One is Illegal between City and Nation', Studies in Social Justice, 4(2) pp. 127-143.

Papademetriou, D. (2005), The regularisation option in managing illegal migration more effectively: a Comparative Perspective, MPI policy brief, retrieved from: http://www.migrationpolicy.org/research/regularization-option-managingillegal-migration-more-effectively-comparative-perspective.

Schech, S. (2013), 'Rescaling sovereignty?', Griffith Law Review, 22, pp.758-803.

Wichmann, N.; M. Hermann; G. D’Amato; D. Efionay-Mader; R. Fibbi; J. Menet; and D. Ruedin (2011), Les marges de manœuvre au sein du fédéralisme: La politique de migration dans le cantons, Commission fédérale pour les questions de migration, $(C F M)$, Bern.

\section{About the Author}

Lucia Della Torre is a researcher in law at University of Luzern, Switzerland and currently jurist at the Swiss Refugee Council. 